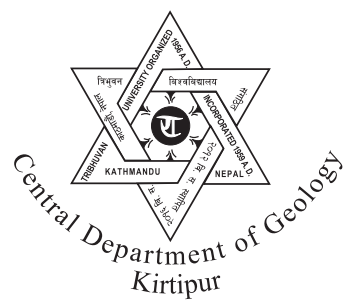

\title{
Geological setting and lithostratigraphy of Bandipur-Gondrang area of Lesser Himalaya, central Nepal
}

\author{
*K. R. Paudyal ${ }^{1}$, L. B. Adhikari ${ }^{2}$, N. Maharjan ${ }^{3}$ and L. P. Paude ${ }^{1}$ \\ ${ }^{1}$ Central Department of Geology, Tribhuvan University, Kirtipur, Kathmandu, Nepal \\ ${ }^{2}$ Department of Mines and Geology, Lainchaur, Kathmandu, Nepal \\ ${ }^{3}$ Regional Seismological Centre, Surkhet, Nepal
}

\begin{abstract}
Detailed geological mapping was carried out in the Bandipur-Gondrang area of Tanahun district to clarify the geological set up and stratigraphy of the area. Wherever possible, geological mapping is based on stratigraphic units proposed by Stocklin and Bhattarai (1977) in central Nepal and the present mapping is the west ward continuation from Mugling-Banspani area (Paudyal and Paudel, 2011). The study area comprises low grade metasedimentary rocks of Nawakot Complex. The rock succession of the area are divided into six formations as the Kunchha Formation, the Fagfog Quartzite, the Dandagaon Phyllite, the Nourpul Formation with four members, the Dhading Dolomite and the Benighat Slates in stratigraphic upwards. The former four formations belong to Upper Nawakot Group and the remaining one belongs to the Lower Nawakot Group of Nawakot Complex (Stöcklin and Bhattarai, 1977). Based on lithology, the Nourpul Formation is divided into the Purebensi Quartzite, the Amdanda Phyllite, the Labdi Khola Member and the Bandipur Slate from bottom to top respectively. The Purebensi Quartzite is lithologically distinct in the field; the Labdi Khola Member is significant with copper and iron mineralization in the area, and the Bandipur Slate is also significant with roofing quality slate, however, the Amdanda Phyllite is mapped as an intervening member between significant lithologies. The rocks of the present study area consist of several sedimentary structures like mud cracks, ripple marks, graded bedding and cross and parallel laminations. A broad GhumauneGondran Synclinorium is mapped in the area. In addition to this, several anticlines and synclines are also mapped in the study area. Jalbhanjyang Thrust has brought the older metasedimentary rocks of the Nawakot Complex over the younger rocks of the same Complex. Some corrections are recommended over the distribution of previously shown lithological units by Stocklin and Bhattarai (1977) around the Ghumaune-Bhut Khola section.
\end{abstract}

\section{INTRODUCTION}

The study area is a part of Lesser Himalaya in central Nepal (Fig.1). It is a fold-and thrust-belt with complex stratigraphy and structures. The low-grade metasedimentary rock succession of the area belongs to the Nawakot Complex (Stöcklin and Bhattarai, 1977), which is further sub-divided into the Lower and the Upper Nawakot Groups separated by an erosional unconformity. Several researchers have carried out geological investigations in the central Nepal Lesser

*Corresponding author:

E-mail address: paudyalkabiraj@yahoo.com
Himalaya and have contributed on geological set up, stratigraphy and mineral resources (Stöcklin and Bhattarai, 1977; Stöcklin, 1980; Sakai, 1985; Hirayama et.al. 1988; Dhital 1995; Jnawali and Tuladhar, 1996; Paudel and Arita, 2000; Dhital et al., 2002; Sah, 2007). However, there are still several discrepancies on the stratigraphy of the Nawakot Complex. Among them one main problem is the identification of lithological units following the type section along the strike and hence the misleading of the tectonic structures. To overcome the existing controversies of stratigraphy of the Lesser Himalaya, detailed geological mapping was started from Muglin and was continued to the west in 


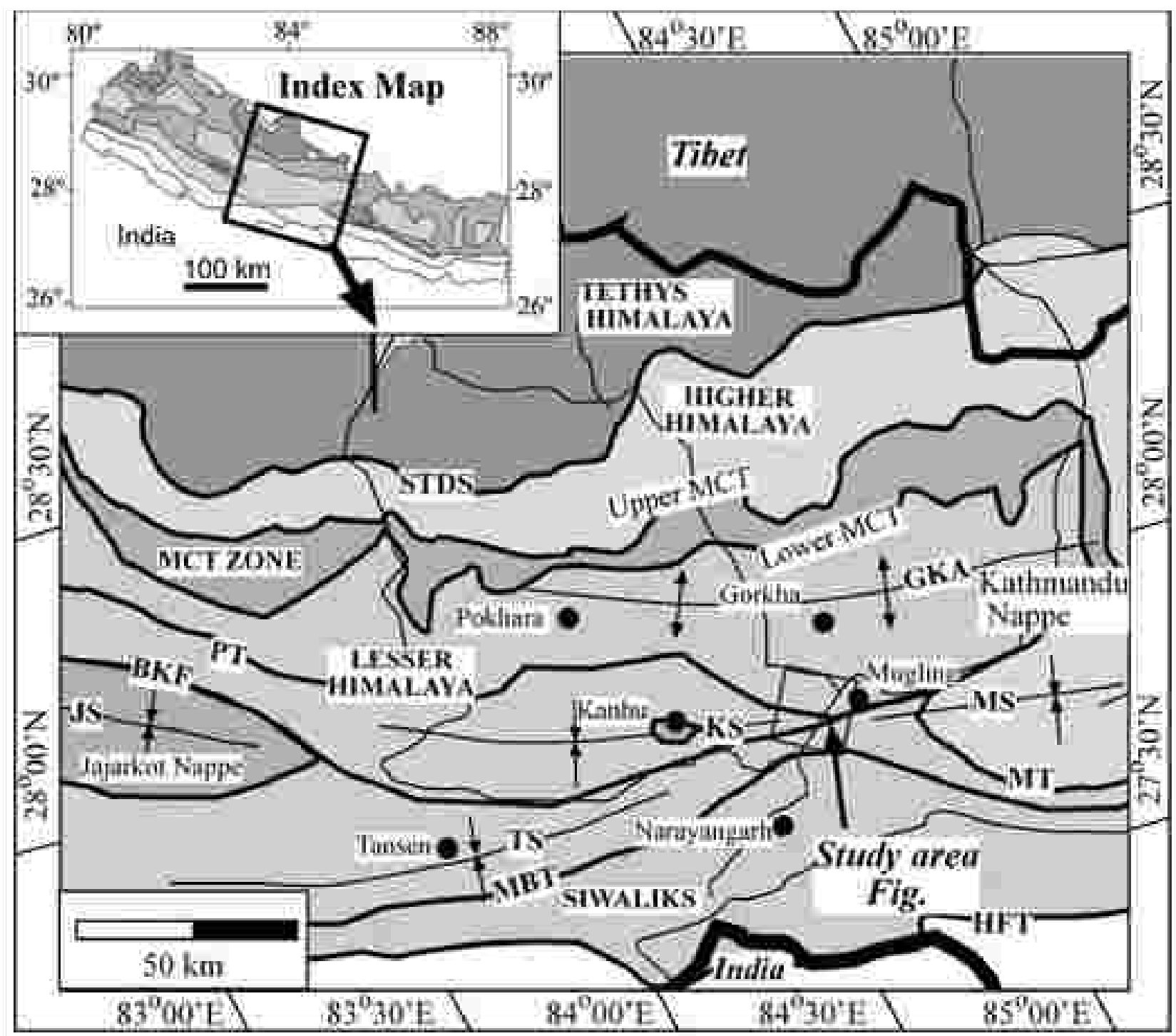

Fig. 1 Location map of the study area; MT = Mahabharat Thrust, MBT = Main Boundary Thrust, $\mathrm{ST}=$ Samari Thrust, and CCT $=$ Central Churia Thrust; STDS-South Tibetan Detachment System. MCT-Main Central Thrust.MBT-Main Boundary Thrust. HFTHimalayan Frontal Thrust. MT-Mahabharat Thrust. BKF-Bari Gad-Kali Gandaki Fault. PT-Phalebas Thrust. MT-Mahabharat Thrust. GKA-Gorkha-Kunchha Anticlinorium. TS-Tanahu Syncline. KS-Kahau Synclinorium. JS-Jajarkot Synclinorium.

Banspani-Bandipur-Damauli areas. Geology of the Mugling-Banspani has been described in Paudyal and Paudel (2011). The present work is the continuity of the geological mapping westward from the Banspani area.

\section{PREVIOUS STUDIES}

Many authors have included this area in their regional geological investigation of central Nepal (Auden 1934; Bordet et al. 1964; Hagen 1969; Arita et al. 1973; Colchen et al.1980). However, very few researchers have shown stratigraphic details of the present study area. Stöcklin and Bhattarai (1977) and Stöcklin (1980) have prepared a detailed geological map of central Nepal. Part of the present study area ( Muglin-Bhut Khola area) falls in the map of Stöcklin and Bhattarai (1977) (Fig. 2). Their map shows that area comprises the Kunchha Formation, Fagfog Quartzite, Dandagaon Phyllite, Nourpul Formation, Dhading Dolomite and Benighat Slates from bottom to top, respectively (Fig. 3). They have also shown two quartzite members (Anpu Quartzite and Banspani Quartzite) and one phyllite member (Labdi Phyllite) within the Kunchha Formation. 
The Nourpul Formation contains a prominent quartzite member at the base (Purebensi Quartzite). The units have been repeated several times in the area by faults and folds. The western closure of the Mahabharat Synclinorium (Jalbire Syncline) is observed at Jalbire, southwest of Mugling.

Department of Mines and Geology has complied the geological maps of the central Nepal Lesser Himalaya in 1:50,000 scale (DMG, 1987). According to their map (Fig. 4), the oldest unit is the Ranimatta Formation (Rm), an equivalent to the Kunchha Formaton. It is followed up section by the Naudada Formation $(\mathrm{Nd})$, the Ghanpokhara Formation (Gp), the Galyang Formation (Gl) with Baitadi beds (Ba), the Sangram Formation (Sg), the Syangja Formation (Sy), and the Lakharpata Formation (Lk), respectively. However, it is very difficult to correlate their units with that of Stöcklin and Bhattarai (1977).

Paudyal and Paudel (2011) has prepared a geological map of the Mugling-Banspani area central Nepal in $1: 25,000$ scale tried to further clarify the lithostratigraphy of the area (Fig. 5). The study showed some discrepancies in the stratigraphic classification of Stöcklin and Bhattarai (1977) and Stöcklin (1980). According to them, (1) the Anpu Quartzite of the Kunchha Formation with unclear stratigraphic position is the westward extension of Fagfog Quartzite, (2) the Banspani Quartzite is the continuous extension of the Purebensi Quartzite which was confirmed by the lithological similarity and stratigraphic position (3) The Labdi Phyllite is equivalent to the Dandadagaon Phyllite, (4) the Nourpul Formation is clearly divisible into three units: the lower quartzite member (Purebensi Quartzite), middle phyllite member (Amdanda Phyllite) and upper carbonate member with a thin succession of cyclic deposit of typical Nourpul of Stöcklin and Bhattarai (Labdi Khola Carbonate of Paudyal and Paudel, 2011). It consists of phyllite, metasandstone, pink dolomite and pink quartzite.

\section{LITHOSTRATIGRAPHY}

Detailed geological map and its cross section of the Bandipur-Gondrang area were prepared in the scale

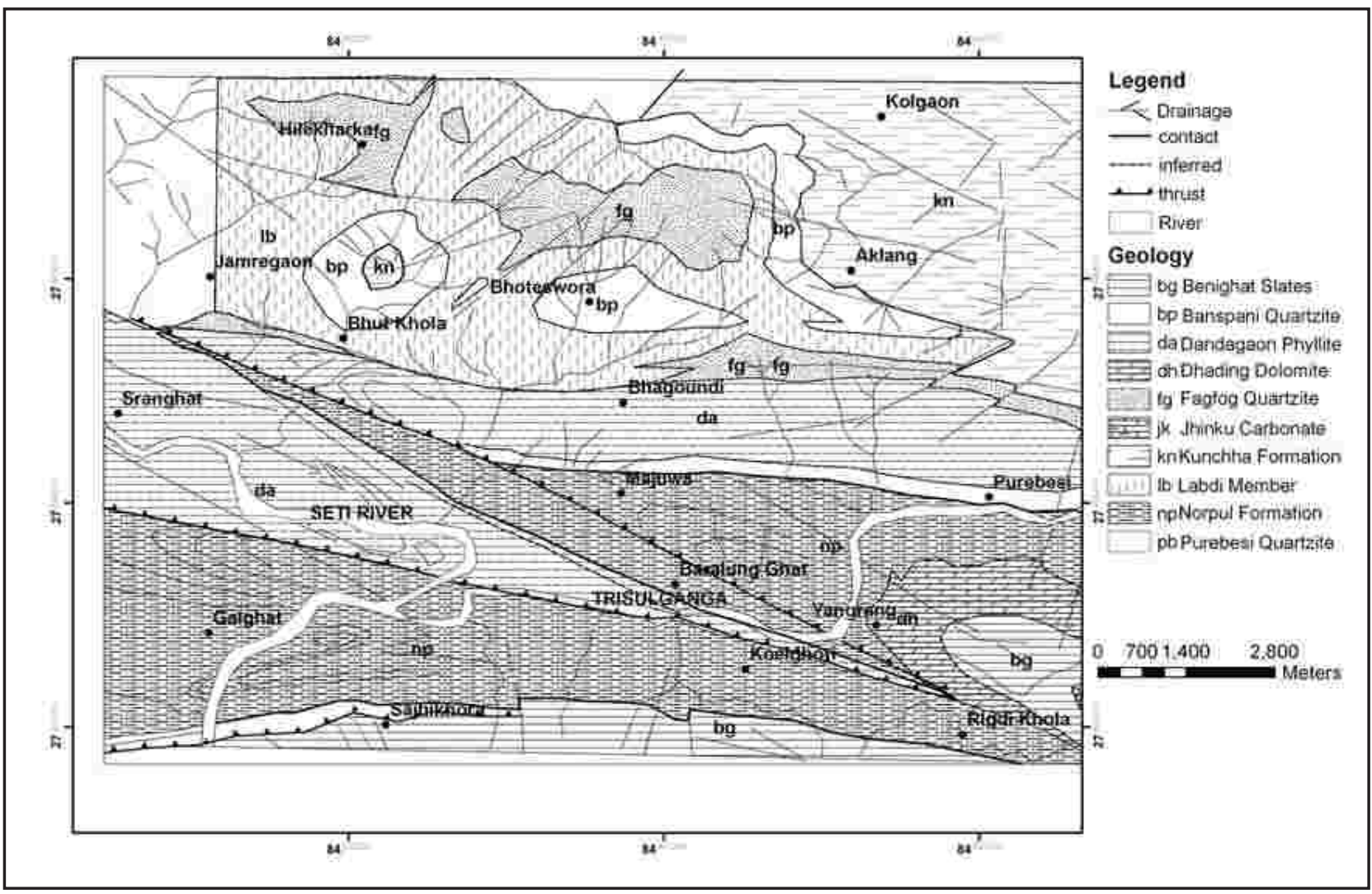

Fig. 2: Geological map of Banspani Bhutkhola area of central Nepal, Lesser Himalaya (after Stöcklin and Bhattarai, 1977). 


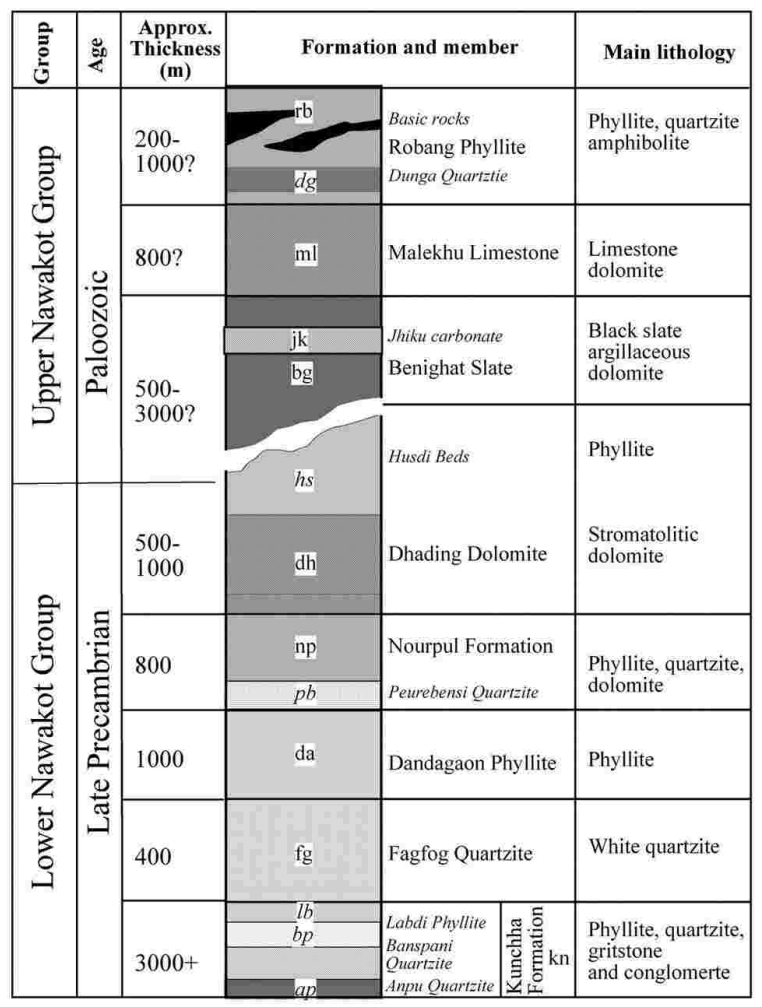

Fig. 3: Lithostratigraphy of Nawakot Complex proposed by Stöcklin and Bhattarai (1977).

1:25,000 (Figs. 6 and 7). Wherever possible, mapping was carried out based on the lithological units established by Stöcklin and Bhattarai (1977), Stöcklin (1980) in central Nepal. The main aim of the mapping was to extend the lithological units westward from Banspani area of Paudyal and Paudel (2011) towards Gondrang. Detailed columnar sections, route maps and sketches were prepared along the rivers, rivulets, trails and roads wherever possible. Traverses were set to follow the marker beds especially quartzites and dolomites along their strikes.

Present mapping revealed that there are discrepancies in the stratigraphic classification of Stöcklin and Bhattarai (1977), Stöcklin (1980) and Department of Mines and Geology (DMG, 1987). The rocks of Kunchha Formation and its members Labdi Phyllite and the Banspani Quartzite are not exposed in the GhumauneBhut Khola area as shown in Figure 2 and Figure 4. The core of Ghumaune-Ghondrang Synclinorium (named after this study) is occupied by the Benighat Slates not by Dandagaon Phyllite. This can be verified

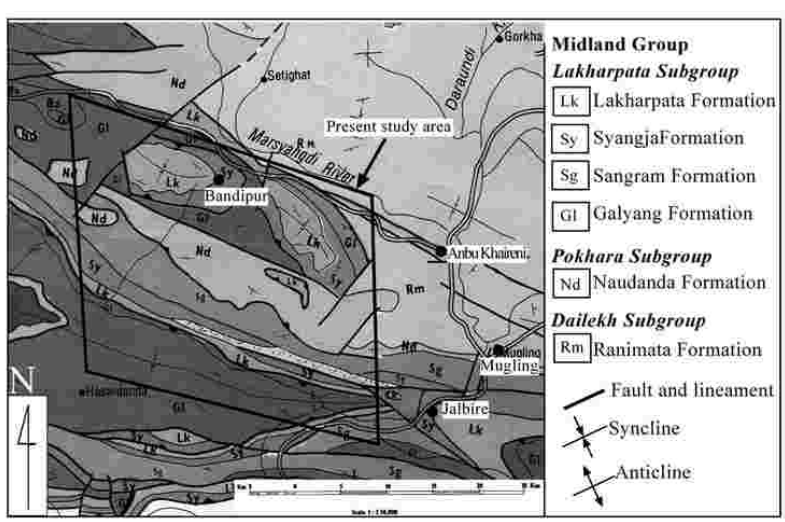

Fig. 4 Geological map of central Nepal Lesser Himalaya after Department of Mines and Geology (1987).

by the lithological similarity and existing stratigraphic position. Characteristics of each lithological unit are described below.

\section{Kunchha Formation}

The rocks of the upper parts of Kunchha Formation are exposed within the small area of present map, at the left bank of Marshayndi Nadi, east of Bhoteswara (Fig. $6)$. It consists of ash grey to dark grey, fine grained phyllite and grey to greenish grey fine grained metasandstone. The metasandstones are medium to thick bedded $(50 \mathrm{~cm}$ to $1.5 \mathrm{~m}$ ) with faint laminations.

\section{Fagfog Quartzite}

The Fagfog Quartzite has been mapped as a continuous extension from Mugling and Anpu Khaireni (Paudyal and Paudel, 2011). However, only a part of

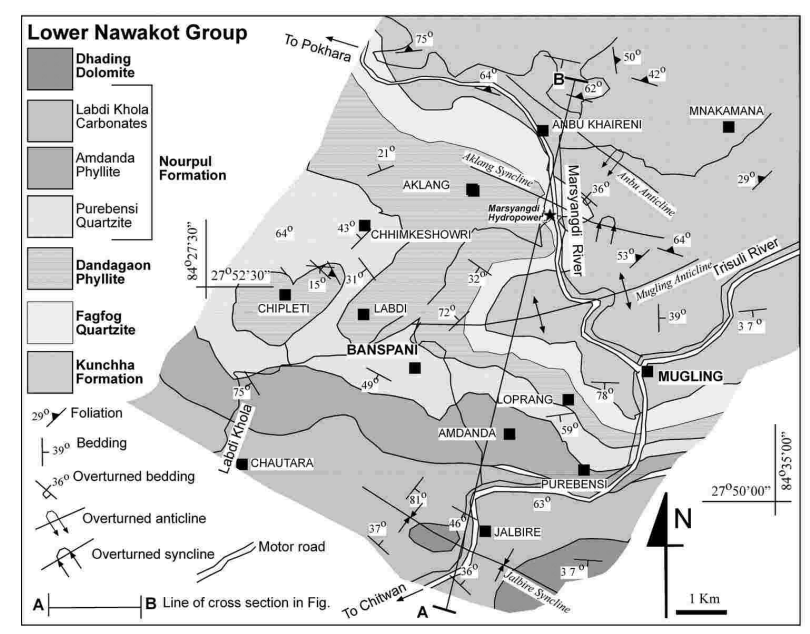

Fig. 5 Geological Map of Muglin-Anbu Khaireni-Labdi area (after Paudyal and Paudel,2011) . 


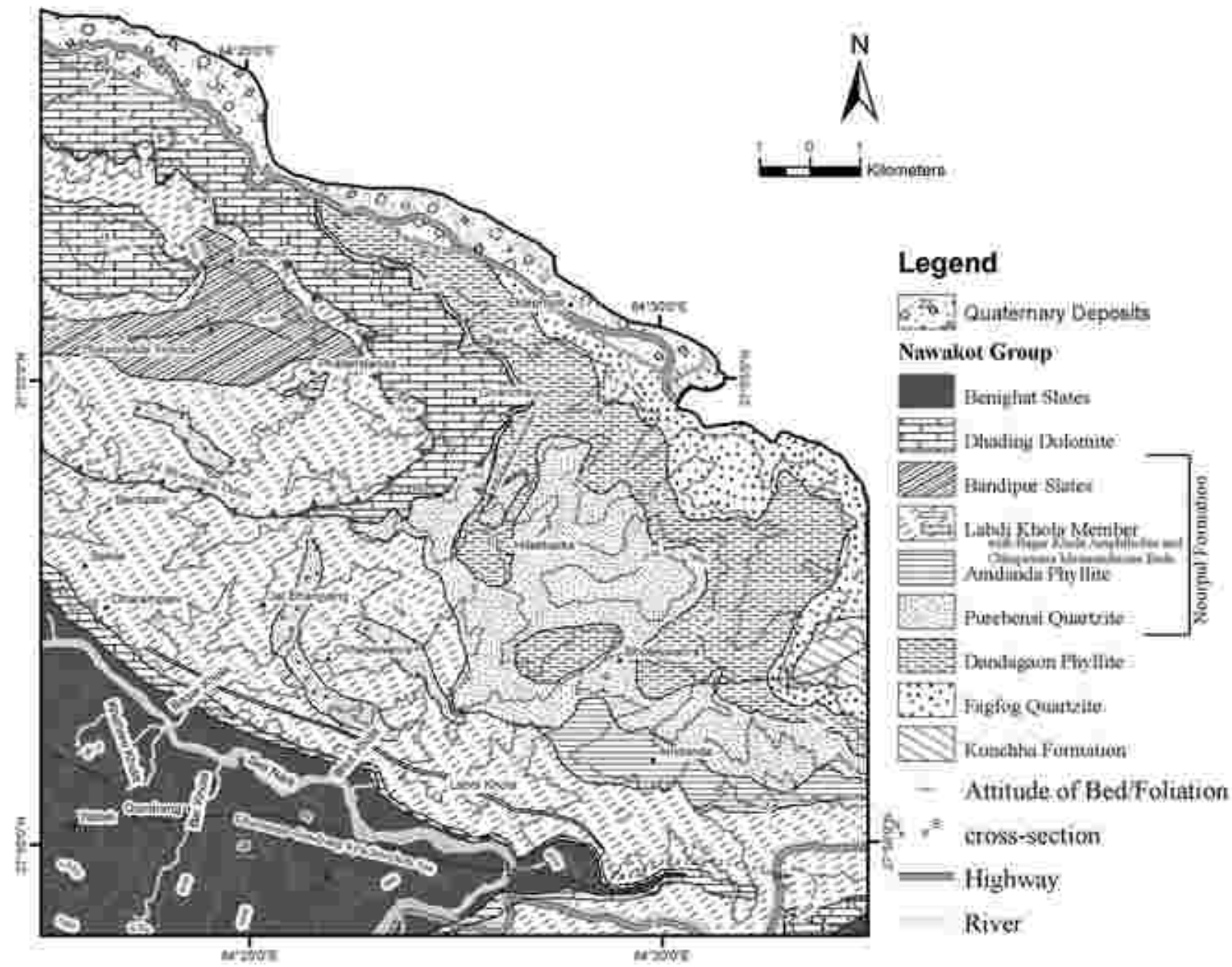

Fig. 6 Geological Map of Bandipur Gondrang area of Tanahun district central Nepal, Lesser Himalaya.

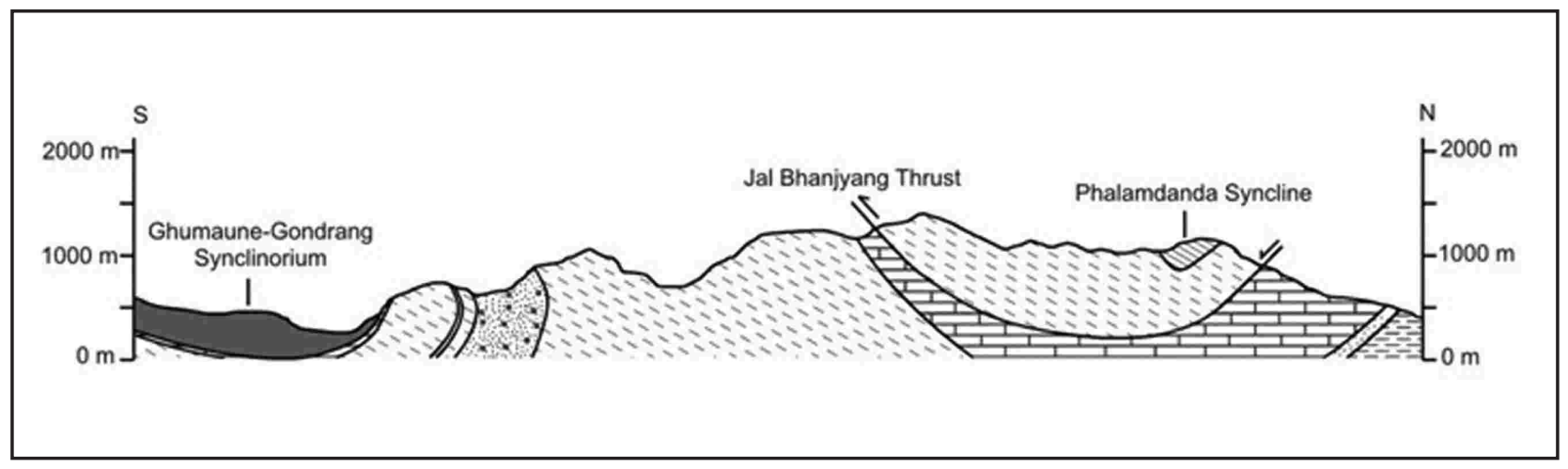

Fig. 7 Geological Cross-section along the line X-Y from Fig. 6. 
the Fagfog Quartzite is exposed in the present study area. It consists of medium- to thick-bedded $(50 \mathrm{~cm}$ to $2 \mathrm{~m}$ ) white quartzite with thin $(1 \mathrm{~cm})$ partings of grey, fine-grained soapy phyllite. In weathered outcrops, the quartzite shows reddish, yellowish or pale orange color. The beds are usually parallel and continuous to several meters. Parallel laminations and oscillation ripples are observed in the outcrops. The Fagfog Quartzite is followed up section by the Dandagaon Phyllite with sharp contact. The thickness of the unit is about $400 \mathrm{~m}$ in the studied section.

\section{Dandagaon Phyllite}

It comprises the succession of black pelitic phyllite and dark grey psamatic phyllite intercalated with calcareous grey phyllite, dark grey fine grained thin bedded metasandstone and dirty grey quartzite. The thickness of phyllite beds varies from $1 \mathrm{~cm}$ to $0.5 \mathrm{~m}$ and that of quartzites with $1 \mathrm{~cm}$ to $30 \mathrm{~cm}$. Occasionally, thin layers of dolomite beds are also found within the phyllite and dirty white quartzite succession. The lithology as a whole reflects darker tone in outcrop and do not contain gritty phyllites as in the Kunchha Formation which makes the main difference between these two formations. The dark grey phyllite of Dandagaon Phyllite is often strongly deformed and exhibit crenulation cleavage. A few sporadic dark grey quartzite and grey lenticular carbonate beds are commonly found within calcareous phyllite and rare intercalation of grey, fine grained, thin to medium bedded metasandstones.

The Dandagaon Phyllite in Chipleti area forms an inliar (Fig.6). The lithology consists of grey, compact, laminated, soapy phyllite in alternation with greenish grey, medium to coarse-grained, medium to thick bedded $(>60 \mathrm{~cm})$ sandstone as a broad inlier surrounded by younger rocks of Purebensi Quartzite. In weathering outcrops, phyllite shows grey color whereas metasandstone shows brown, purple and greenish- grey colors. Metasandstones are found fairly lineated. On the way to Chipleti from Labdi, metaconglomerate having elongated and deformed clasts (size: $0.2-5.0 \mathrm{~cm}$ ) are observed. Boudinage of quartz $(\mathrm{d}=1.5 \mathrm{~cm})$ and quartz veins parallel to foliation are found in phyllites frequently. Phyllites are internally folded lying between two competent beds of metasandstonesThe Dandagaon Phyllite is extensively distributed to Hilekharka, Chipleti and Tilbari areas, south west of Bandipur (Fig.6). It is followed up section by the Purebensi Quartzite, a basal member of the Nourpul Formation with sharp and conformable contact. Total thickness of the Dandagaon Phyllite is about $650 \mathrm{~m}$.

\section{Nourpul Formation}

The Nourpul Formation is exposed extensively in the study area. It is a succession of varied type of lithology like grey phyllite, grey-green slate, grey metasandstone, pink dolomite, pink, grey, dirty white quartzite etc. Based on the lithological characteristics and distribution, Nourpul Formation is divided into four members from bottom to top as the Purebensi Quartzite, Amdanda Phyllite, Labdi Khola Member and Bandipur Slate respectively.

\section{Purebensi Quartzite}

The Dandagaon Phyllite is sharply followed up section by the Purebensi Quartzite. It is well distributed in the Bhoteswara and east of Hillekharka (Fig. 6). It forms a very steep topography (about 70-80 degree inclination). This unit is dominated by dirty white to ash grey, parallel- and cross-laminated quartzite (80\%) intercalation with grey, crenulated, and coarse-grained phyllite (20\%). The quartzite is coarse-grained, mediumto thick-bedded ( $50 \mathrm{~cm}$ to $1.2 \mathrm{~m}$ ) with abundant wave and current ripples (Fig. 8). The cross-beddings shows the beds are in right side up position. A faint weathering on quartzite shows the yellow and rusting coloration. In the study area quartzite forms prominent peaks. The contact of the Purebensi Quartzite with the overlying Amdada Phyllite is sharp and conformable which is easily identified in the field by vegetation and relief (Fig. 9).The thickness of the Purebensi Quartzite is more than $250 \mathrm{~m}$ in studied section. It is sharply followed up section by the Amdanda Phyllite.

\section{Amdanda Phyllite}

The name of this member is after the village Amdanda of Abukhaireni VDC of Tanahu district (Paudyal and Paudel, 2011). It consists of monotonous succession of strongly laminated, grey, psammitic phyllite with subordinates of pellitic phyllites and grey metasandstone.

The Amdanda Phyllite is exposed around the Amdanda area. In many exposures, phyllite alternates 


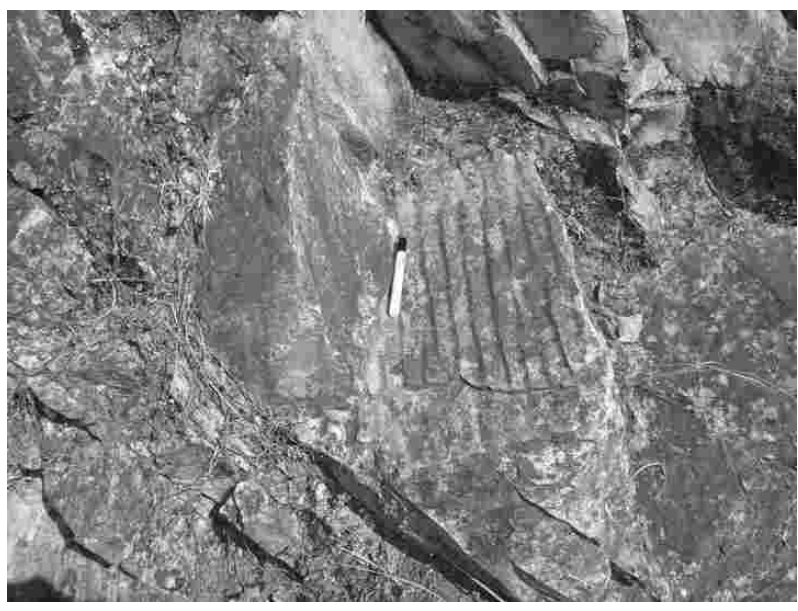

Fig. 8 Asymmetrical ripple marks as seen in the beds of Purebensi Quartzite in Khasran.

with greenish grey, laminated, medium to thick bedded metasandstone. Laminae are ash grey to lead grey and $1 \mathrm{~mm}$ to $4 \mathrm{~mm}$ in width (Fig. 10). The color of phyllite is bluish green in places with vivid, yellow, pink, purple and violet variations in weathered condition. Quartz veins are frequent and show the cross cutting relation with laminae. The thickness of laminae varies from 1 $\mathrm{mm}-1 \mathrm{~cm}$. The outcrop is non-calcareous in nature. The distribution of the Amdanda Phyllite is not continuous throughout the area.The average thickness of this member is $750 \mathrm{~m}$. (Fig. 7).

\section{Labdi Khola Member}

The name of this member has been derived from the Labdi Khola, a small stream of Seti Nadi, $3 \mathrm{~km}$ south west of Ghumaune (name is modified from Labdi khola Carbonate of Paudyal and Paudel, 2011 after this study). It comprises the succession of intercalation of slate, phyllite and metasandstone with frequent interlayers of dolomite and quartzite. Mostly the upper middle part of the Labdi Khola Member consists of mudcracks and ripple marks in sandy shale. A cyclic deposit of grey phyllite, dirty grey metasandstone, pink dolomite and quartzite is found at the very top of the Labdi Khola Member which Stöcklin and Bhattarai (1977) termed the typical Nourpul Formation. Along the road section from Kaphalswara to Dharampani, a succession of medium- to thick-bedded grey coarse- grained metasandstone and gray psammitic phyllite in the varied proportion from 2:1 to $1: 1$ is observed. In some places,

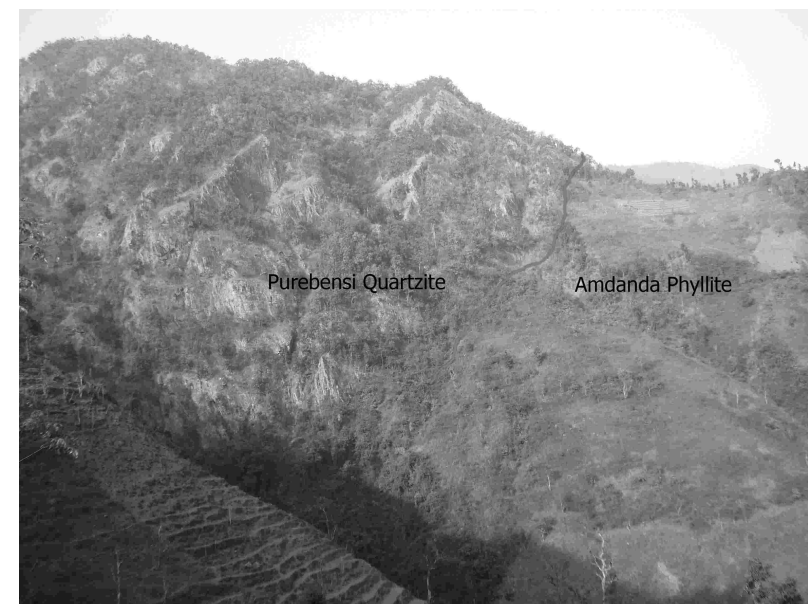

Fig. 9 Sharp contract between Purebensi Quartzite and Amdada phyllite, facing east.

intercalation of red shale, siliceous pink dolomite, and dirty grey quartzite is also observed. The upper part of the Nourpul Formation is characterized by the intercalation of greenish grey metasanstone with ash grey to green shale, grey, fine grained psamatic phyllite with occasional beds of grey to pink dolomites and quartzites. The succession is mapped in Kaphalswara, Dharampani, Bagar Khola section, Bhut Khola section, Labdi Khola section, Khare Khola section, Simaltal areas (Fig. 6). Sedimentary structures like mudcracks and ripple marks are also observed in the succession. In Khare Khola section, the succession consists of bluish grey, purple, pelitic phyllite intercaltion with grey psammitic phyllite and grey metasandstone. Phyllite consists of detrital mica and is also intercalated with pink siliceous dolomite. The transitional contact with lineated pelitic and psammitic shale and phyllite of

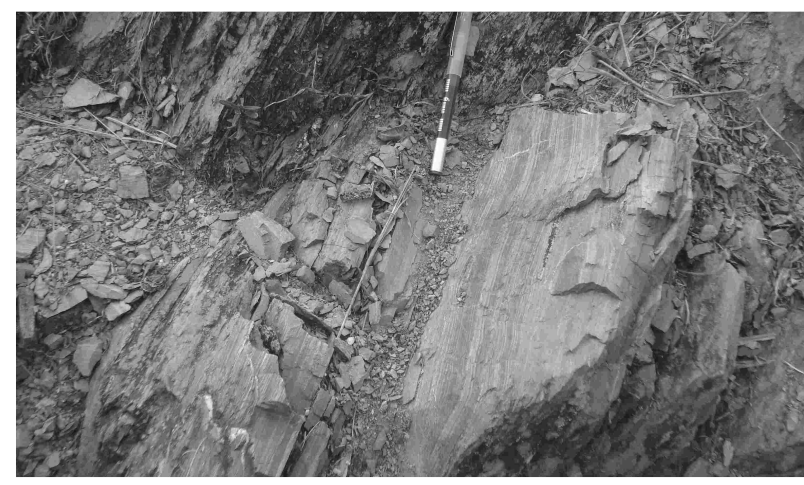

Fig. 10 Amdanda Phyllite with distinct laminations observed in Dumsidhunga, facing SE. 
Amdada Phyllite is also observed.

In Labdi Khola section the Nourpul Formation is composed of the medium to thick lenticular beds of pink, ash grey silicious dolomite intercalated with grey phyllite. This succession has been continuously mapped in the Bhut Khola section where the Nourpul Formation dominantly consists of pink dolomite in the cyclic deposit as described above. Water fall and pot hole structures are developed in the river section due lithological character of carbonate and non-carbonate intercalations. In Ghumaune, it consists of intercalation of pink quartzites and green phyllites in the ratio of 1:1. Faintly preserved ripple marks are usually found in the beds of grey quartzite. The contact between the Nourpul Formation and the overlying Dhading Dolomite is sharp. The thickness of this formation is about $570 \mathrm{~m}$ in the study area. The lithology of the member is not uniform throughout the area and the Chhapswara Metasandstone Beds and the Bagar Khola Amphibolite bodies are mapped within the Labdi Khola Member.

\section{Chhapswara Metasandstone Beds}

The name of this Bed is derived from the Chhapswara village, south east of Jalbhanjyang of Deurali VDC in Tanahun district (Fig. 6). It is a succession of dominantly fine- to medium-grained metasanstone with subordinates of phyllite. It is also mapped around the Dheregaon, Jalbhanjyang, Sinnar Khola- Bhut Khola section and Kulmun. It consists of lead grey to ash grey, fine- to coarse grained, and medium -to thick-bedded $(40 \mathrm{~cm}$ to $1.5 \mathrm{~m}$ ) metasandstone with minor intercalation of

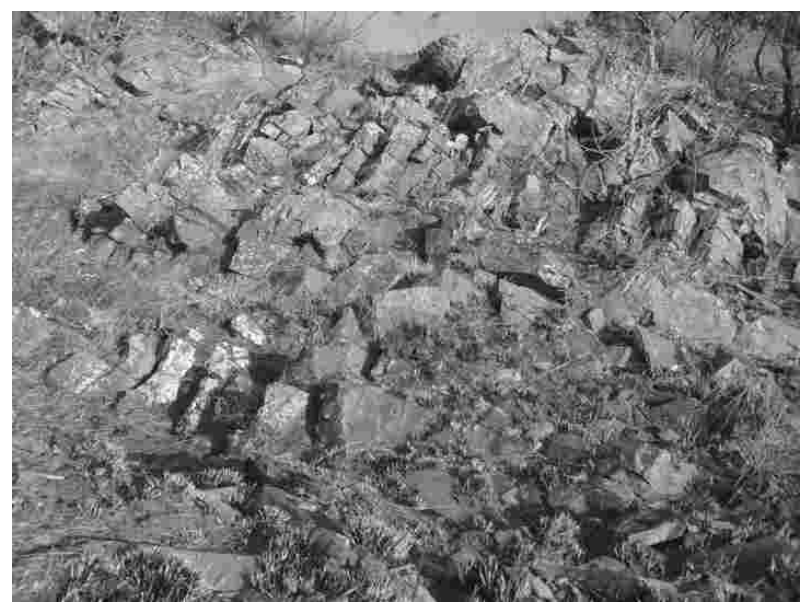

Fig. 11 Outcrop of Chhapswara Metasandstone Beds, at Dheregaon, facing north.

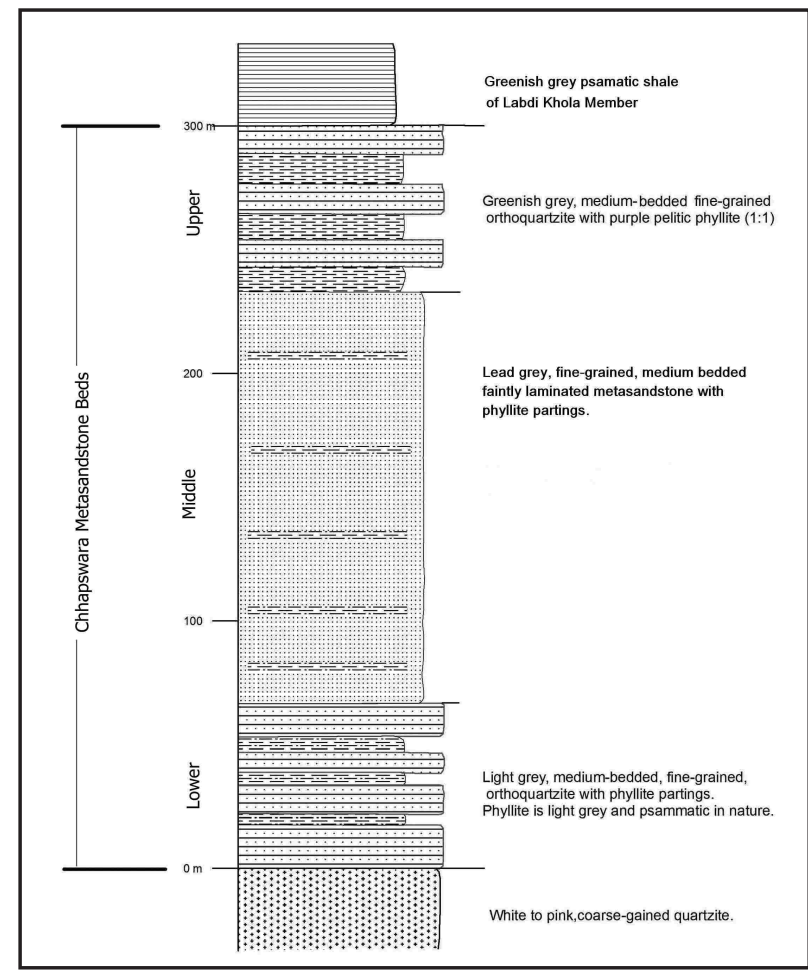

Fig. 12 Columnar section of Chhapswara Metasandstone succession exposed along Darsibhanjyan to Chhapswara foot trail.

grey, purple, fine-grained phyllite (Fig.11). The Metasanstone Bed occassionaly consists faint laminations. The lower part of the bed consists of light grey, medium-bedded, fine-grained metasandstones with light grey, psammitic phyllite partings. In middle section, the proportion of metasandstone increases where it contains the faintly preserved parallel laminations. The top part is composed of greenish grey, fine- grained, medium-bedded metasandstones and purple pelitic phyllite in equal proportion. The generalized columnar section of the Chhapswara Metasandstone sequence is shown in Fig. 12. The lower and upper contact of this member with middle part of the Nourpul Formaton is transitional everywhere. The total thickness of this unit is about $300 \mathrm{~m}$.

\section{Bagar Khola Amphibolites}

The name of this metabasite bodies is taken from the Bagar Khola, a tributary of Seti River, which is about $7 \mathrm{~km}$ west from the Ghumaune towards Damauli. The exposure is located about $1 \mathrm{~km}$ upstream from the confluence of Seti River and Bagar Khola (Fig. 13). The amphibolite is dark green due to some acicular 


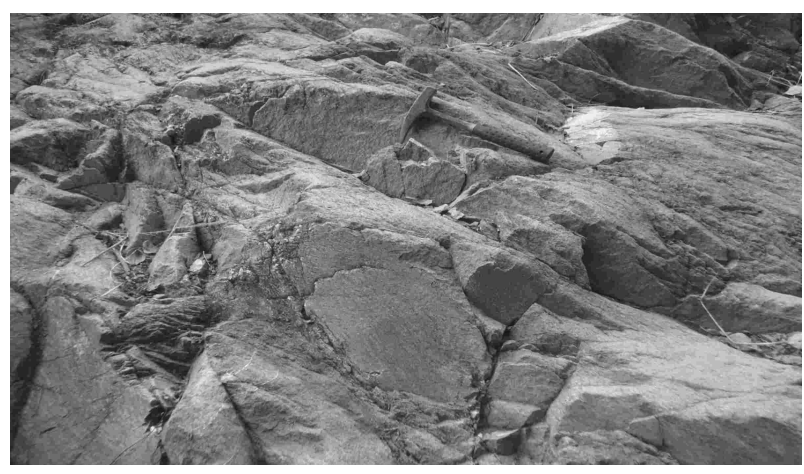

Fig. 13 Outcrop view of Bagar Khola amphibolites at Bagar Khola about $150 \mathrm{~m}$ upstream from the confluence of Seti River and Bagar Khola.

minerals like actinolite and tremolite. It is massive and granoblastic with distinct mineral lineation. The lineation is due to the presence of actinolite and tremolite. No any xenoliths and country rock inclusions are observed. It does not react with dilute hydrochloric acid. It is uniterruptly exosed in Dharampani, Sarang, Bhut Khola section, Ratanpur, Labdi Khola setion, Donran and Khasran areas (Fig. 6). The contact of amphibolite with adjacent rocks of the upper part of the Nourpul Formation is sharp and conformable. The thickness of the amphiblite is not uniform and it varies from $25 \mathrm{~m}$ to $80 \mathrm{~m}$ in the study area. The rocks in Labdi Khola section (located about $1.5 \mathrm{~km}$ upstream from the confluence of Seti River and Labdi Khola), is wellexposed as a green schist and measured the maximum thickness about $80 \mathrm{~m}$. The Bagar Khola Amphibolite is highly weathered as brown to grey pelitic phyllite like appearance in ridge sections which makes it difficult to be distinguish from weathered phyllite and slates.

\section{Bandipur Slates}

It is well developed at Bandipur and its adjacent areas. The rock succession consists of the monotonous grey, faintly laminated slates with subordinates of grey, coarse grained, medium bedded metasandstones (Fig. 14). The thickness of individual sheets of the slates is measured in the range of millimeter to few centimeters. In most of cases the bedding is found parallel to the foliation or cleavages. The metasandstones are laminated and the cross laminations show the beds overturned locally (Fig.15). The metasandstones in some palaces

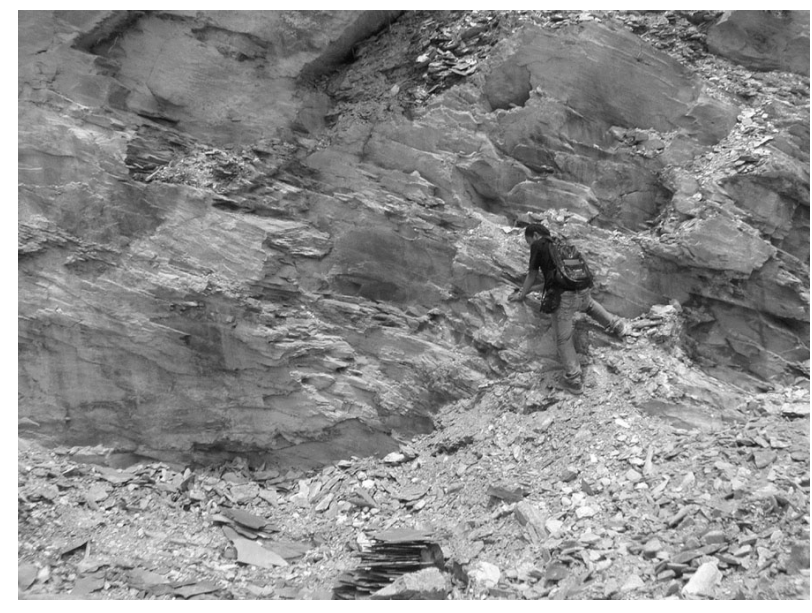

Fig. 14 Outcrop view of Bandipur slate at the Downslop of Bandipur village.

show the growth of small well developed rock crystals. It is mapped as the top most unit of the Nourpul Formation.

\section{Dhading Dolomite}

It consists of monotonous succession of bluish grey, massive, silicious dolomite with faintly preserved algal mats and columnar stromatolites. Grey, fine grained and crenulated phyllite partings and intraformational clasts (max size $2.5 \mathrm{~cm}$ ) are not uncommon within the Dhading Dolomite. It is distributed along the immediate hills of the left bank of Seti River and right bank of Trishuli River (Fig. 6). Thickness of the Dhading Dolomite is not uniform in the area; it is about $20 \mathrm{~m}$ thick in Ghumaune and it increases to $100 \mathrm{~m}$ in Bagar Khola Dhap area.

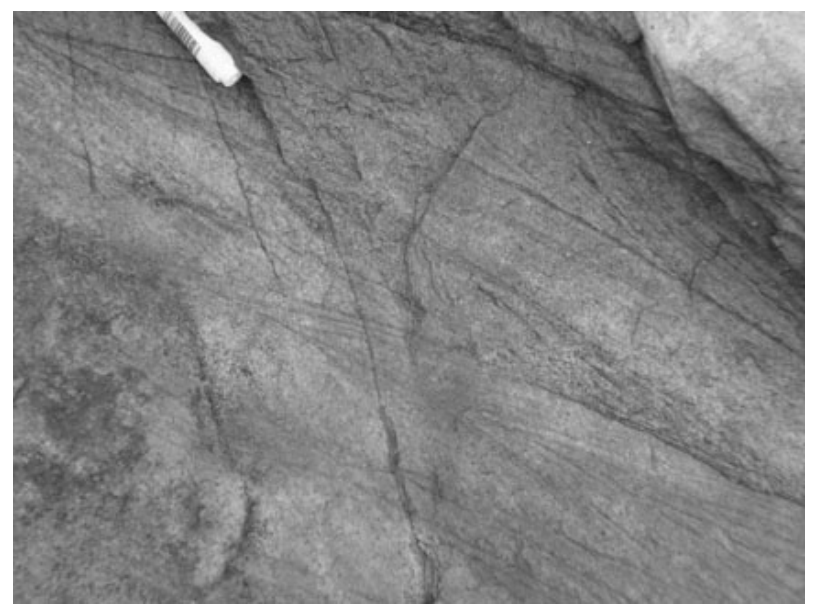

Fig. 15 Well developed cross laminations in metasandstone beds of Bandipur Slate observed in Bandipur area. 
Weathered outcrops display elephant skin appearance, honey-comb- structures and some leaching features with many cavernous surfaces. The same type of lithology is also observed in Dharampani and its eastward areas.

In eastern parts of Labdi khola and Ghumaune areas, the Dhading Dolomite is found limited in between the rocks of Nourpul Formation indicating the clousure of the Ghumaune-Gondrang Synclinorium and the contact between these two formations is sharp and conformable. The average thickness of this formation is about $80 \mathrm{~m}$. The variation in thickness is due to intense folding of rocks. The stromatolites show the normal stratigraphic sequence in the area.

\section{Benighat Slates}

It consists of monotonous succession of dark grey, finely laminated slate. Some calcareous beds of metasiltstones are not uncommon within the slates. Rocks of this formation are exposed in both sides of Seti River valleys and ridges. The thickness of this formation has been doubled in some places due to the repetition of beds by folding. In Bhut Khola section the phyllite is dark grey to charcoal black, finelylaminated and internally folded. The outcrop consists of $60 \%$ phyllite and $40 \%$ calcareous metasiltstone. In Labdi Khola section near to confluence of Labdi Khola and Seti River, the rock consists of carbonaceous slate with subordinates of dark grey, thin- to medium-bedded siltstone. The characteristic dark slate is usually observed

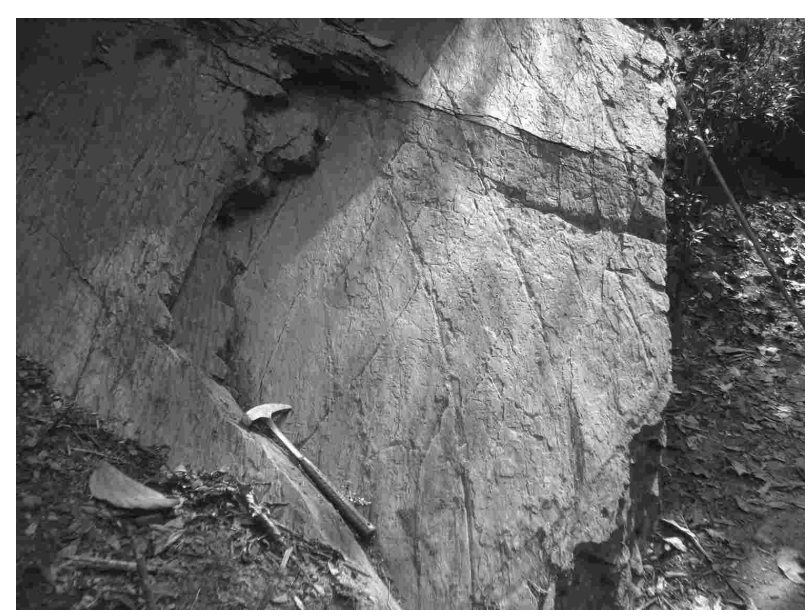

Fig. 16 Mudcracks and ripple marks in the Labdi Khola Member observed in Baralungbesi, left bank of Trishuli, 9 kilo from Muglin to Narayangar, facing south.

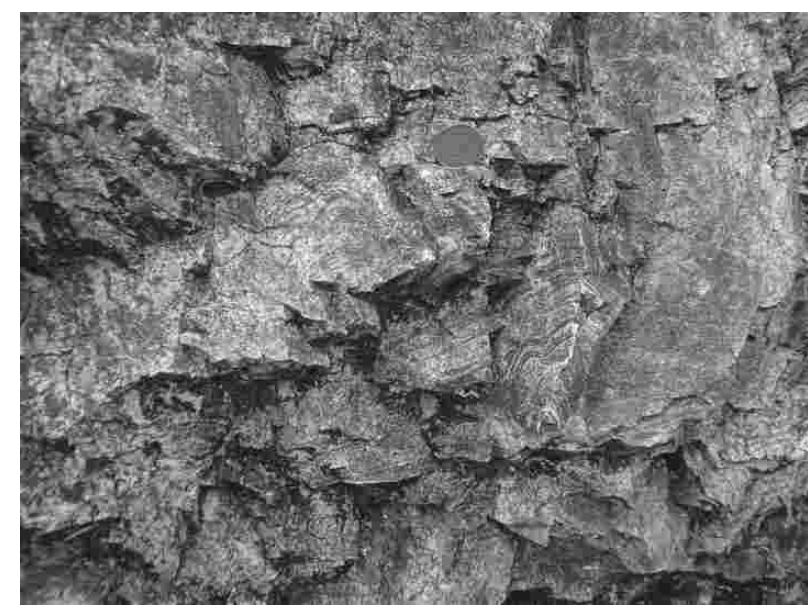

Fig. 17 Columnar stromatolites in Dhading Dolomite in MuglinNarayangar road near Gaighat, facing south.

in fresh outcrop along the river banks but in weathered exposures of the hill slopes rocks show much lighter color like lead-grey, silver-grey, pink-pale-green etc.

In Bar Khola section, the Benighat Slate contain finely laminated (lamina $=1 \mathrm{~mm}$ to $5 \mathrm{~mm}$ ) slates with increased carbon content. Rare bands of carbonates and coarse-grained metasandstones are also reported. Randomly oriented quartz and gypsum veins are found in slate. A band of polymetallic ore (thickness $=10 \mathrm{~cm}$ ) is also observed. The same type of band is also observed in Jaubari Khola and Khare Khola as its extension. A large area of Watak, Gondran and Ailung is covered by the laminated succession of the Benighat Slates.

\section{PRIMARY STRUCTURES AND THEIR IMPLICATIONS}

\section{Ripple Marks}

Oscillation ripple marks are observed in Purebensi Quartzite and metasandstone of the Nourpul Formation. Some linguoid ripple marks are also observed on the sandy phyllite of the Upper Part of the Nourpul Formation (Fig. 8). Sharp crest of oscillation ripples was used for the younging direction of strata.

\section{Mud Cracks}

Well preserved mud cracks are observed in the psammatic shales of the Nourpul Formation (Fig. 16). These structures indicate the sediment aerial exposure 


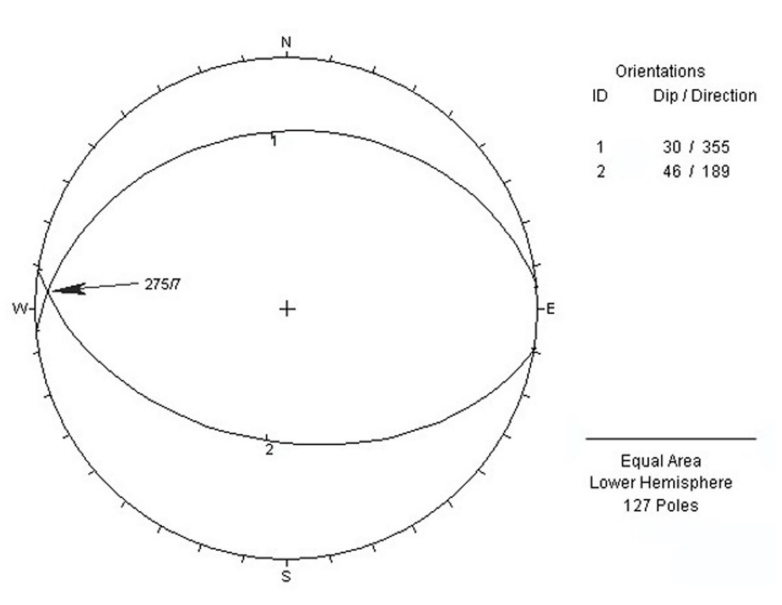

Fig. 18 Sterionet plot of fold (Ghumaune-Gondrang Synclinorium).

from shallow water. The convex surface of the mud crack wedge was used for the younging direction.

\section{Stromatolites}

Columnar stromatolites are found in the massive beds of the Dhading Dolomite (Fig. 17). The convex part of the stromatolites indicates the younging direction.

\section{Gradded Bedding}

Gradded bedding is observed within the Bandipur Slate, at the lower reaches of Bandipur indicating normal stratigraphic position of the area. This clearly indicates that the dolomite sequence of Bandipur area is younger than the Bandipur Slate and is interpreted as the Dhading Dolomite.

\section{Cross Bedding}

Well developed cross beddings are found in metasandstone beds of the Bandipur Slate. The cross beddings show the overturned beds, which is due to the locally folding of the rocks (Fig.15).

\section{SECONDARY STRUCTURES}

\section{Folds}

A number of small to large scale folds of various types and orientations are observed in the study area. A broad Ghumaune-Gondran Synclinorium has been

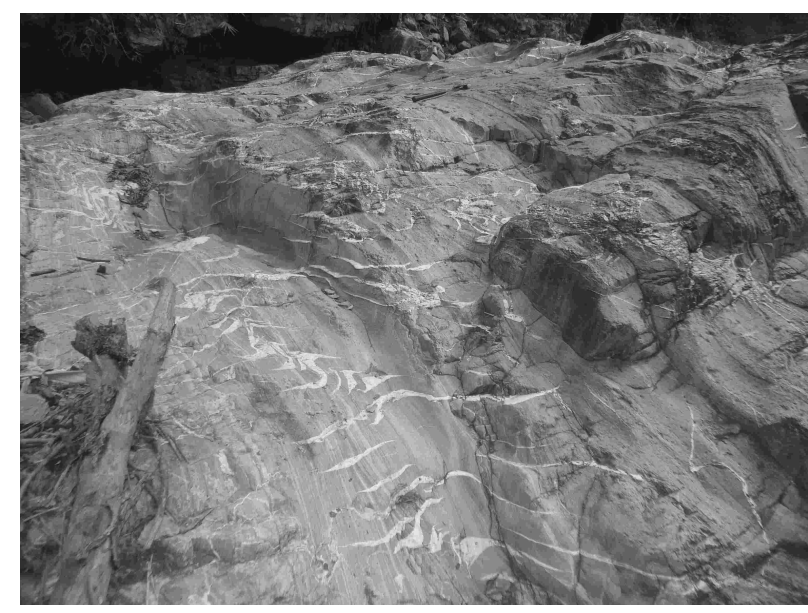

Fig. 19 Tension gash observed in Labdi Khola Member at Labdi.

mapped in the area whose axis has a trend and plunge $275^{\circ} / 7^{\circ}$ (Fig. 18). Other folds are the the Phalamdada Syncline and the Hillekharka Anticline (Fig. 6 and Fig. 7). Core of the Phalamdada Syncline is occupied by the Dhading Dolomite and its trend and plunge is calculated as $297^{\circ} / 9^{\circ}$ respectively. The core of the Hillekharka Anticline is occupied by the older Dandagaon Phyllite. Numerous mesoscale folds are thoroughly observed almost in all pelitic rocks of the area.

A major thrust has been mapped and named as Jalbhanyang Thrust (JT) after this study which has brought the older Nourpul Formation over the Dhading Dolomite (Fig. 6 and Fig. 7). The stratigraphic correlation of the rocks overlying and underlying the JT is shown in Fig. 19. The whole thrust sheet is folded whose trend and plunge has been calculated as $297^{\circ} / 9^{\circ}$ using dips software. A number of outcrop scale faults and shear zones are observed in the field study. In Labdi Khola section a number of shear zones are noticed. Similarly, a broad and distinct shear zone is also observed in Dheregaon on metasanstones of the Nourpul Formation.

\section{OTHER STRUCTURES}

The area is highly deformed and stressed as indicated by numerous folded quartz veins, boudinage structures and shear zones in addition to major folds and thrusts. Upper part of Nourpul Formation and Benighat Slates consists of numerous folded quartz, calcite and gypsum veins and boudinage structure. Tension gash are also observed within the upper part of the Nourpul Formation 


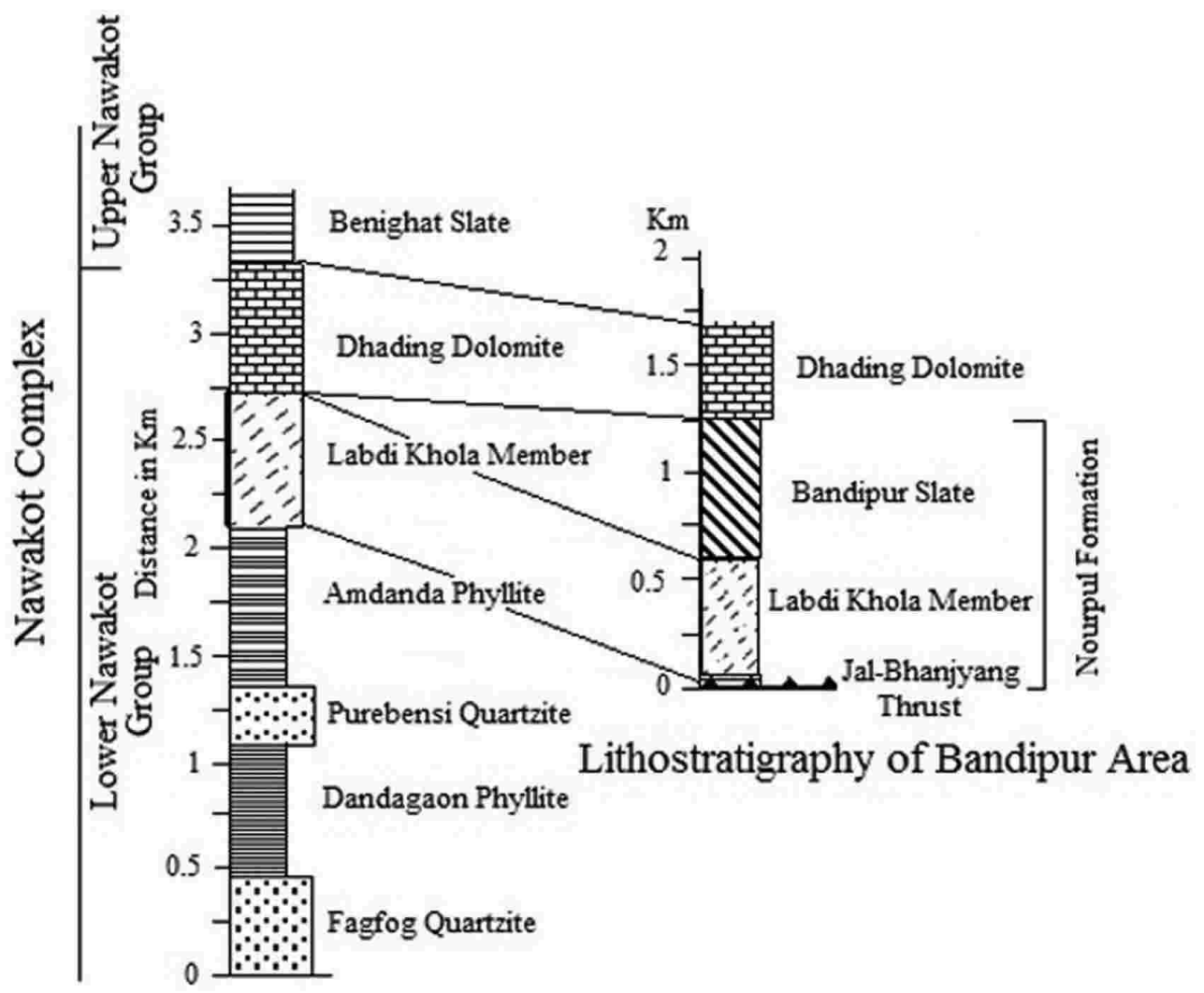

Fig. 20 Comparison of lithostratigraphy of Labdi Khola area and Bandipur area (above the Thrust contact).

in Labdi Khola Carbonates (Fig. 19).

\section{DISCUSSIONS ON \\ LITHOSTRATIGRAPHY OF THE NAWAKOT COMPLEX}

One of the realities of stratigraphic division and correlation in the Nawakot Complex of the Lesser Himalaya is that the stratigraphic units have been defined on the basis of lithology only. Most of the units are unfossiliferous, and radiometric data are rare. Lithological characteristics extensively vary laterally. Deep weathering also adds confusion on identification of rocks, for example, the slates appearing dark black in the wet condition at and around the river section shows light ash grey to silver grey in the ridges. Other rock types such as quartzite, dolomite and metasandstone also show similar kind of complications. Therefore, in the present mapping we made an attempt to map the lithological units westward along the strikes from the
Banspani area up to which the mapping was extended. The present study reveals some significant findings on the lithostratigraphy and geological setting of the area which are summarized in the following points.

1) There are two distinctly mappable quartzite units in the area as the Fagfog Quartzite and the Purebensi Quartzite separating them by a succession of dominantly dark grey phyllite with subordinates of metasandstone, quartzite and dolomite of Dandagaon Phyllite. The thickness of these quartzite units is almost similar and both units contain the oscillation ripples and both parallel and cross laminations. However, there are some markable differences between them especially in color and presence of phyllite percentage. The Fagfog Quartzite is mostly milky white with rare phyllite partings whereas the Purebensi Quartzite is dirty grey with intercalation of subordinates of phyllite sometimes about $30 \%$ grey phyllite. In the present mapping these two quartzite units are mapped extensively along their strikes which gave a clear picture of stratigraphy of the area. 
2) The Nourpul Formation is divisible into four members with several beds. The basal part of the formation is mapped as the Purebensi Quartzite which is followed by the Amdanda Phyllite, the Labdi Khola Member and the Bandipur Slate in stratigraphic up position. The lowermost member (the Purebensi Quartzite) is lithologically distinct, the Labdi Khola Member is characterized by the iron and copper mineralization as well as with distinct matabasite bodies, the uppermost member (the Bandipur Slate) is also significant with roofing quality slate, however, the Amdanda Phyllite, the lower middle part of the Nourpul Formation is mapped as the intervening lithology between two distinct members. The middle member Amdanda Phyllite is not distributed thoroughly in the area. It has made mapping complicated to some extent. The Labdi Khola Member has found many beds within it as the Chhapswara Metasandstone Beds and the Bagar Khola Amphibolite in different places (Fig. 6). Actually, the lithology of Nourpul Formation is confusing with several possible metasedimentary rocks found in the Lesser Himalaya. In present mapping the attempt has made to differentiate the possible members and beds within the Nourpul Formation.

3) In present mapping, core of the Ghumaune Synclinorium is occupied by the rocks of the Benighat Slates which can be suggested by lithological similarity and stratigraphic position. However, the same succession is mapped as Dandagaon Phyllite by Stöcklin and Bhattarai (1977) and as Galyang Formation by DMG (1987).

\section{CONCLUSIONS}

Detailed geological mapping was carried out in Bandipur-Gondran area of the Lesser Himalaya in central Nepal. The area comprises low-grade metasedimentary rocks of the Nawakot Complex. The present mapping is the continuity of the Muglin-Banspani area of Paudyal and Paudel (2011). Wherever possible the mapping was carried out by extending the units of Stöcklin and Bhattarai (1977), westward along the strike from the Mugling and linking them with the type localities. The lithological succession of the area can be mapped into six formations as the Kunchha Formation, the Fagfog Quartzite, the Dandagaon Phyllite, the Nourpul Formation, the Dhading Dolomite and the Benighat Slates in stratigraphic up section where the former five belong to the Lower Nawakot Group and the later one belongs to the Upper Nawakot Group with sharp contact in between the formations. The Fagfog Quartzite consists of monotonous succession of white quartzite with phyllite partings which sharply passes to the Dandagaon Phyllite of dominantly dark grey phyllite. The Nourpul Formation is composed of mixed and diversified lithology. Based on lithology, distribution and stratigraphic position it is further divided into four members as the Purebensi Quartzite, the Amdanda Phyllite, the Labdi Khola Member and the Bandipur Slate from bottom to top respectively. The Purebensi Quartzite consists of monotonous succession of dirty grey quartzite with subordinates of phyllite. The Amdanda Phyllite consists of monotonous succession of laminated phyllite with minor intercalation of metasandstone and limestone. The Labdi khola Member comprises the succession of grey metasandstone, grey phyllite, pink dolomite and pink, grey quartzite in various proportions. It is recognized as the iron and copper mineralization unit. The Chhapswara Metasandstone Beds and the Bagar Khola Amphibolites are also mapped within the Labdi Khola Member in different position. The Chhapswara Metasandstone Bed consists of the grey metasandstone with minor intercalation of grey phyllite whereas the Bagar khola Amphibolite comprises the succession of the metabasites which after retrograde metamorphism in some places has changed to green schist and green phyllite. The perfect mineral lineation and green color are due to the presence of acicular minerals like chlorite, actinolite and tremolite and prismatic hornblendes. The top most part of the Labdi Khola Member consists of cyclic deposit of phyllite, metasandstone and pink dolomite and quartzite similar to the typical Nourpul Formation of Stöcklin and Bhattarai (1977). The Bandipur Slate is composed of a succession of dominantly dark grey to ash grey slate with subordinates of faintly laminated metasandstones at the top of the Nourpul Formaton. It is recognized by the presence of high quality roofing slate. The Dhading Dolomite is a succession of monotonous dolomite with rare phyllite partings which sharply passes to monotonous slates with subordinates of metasandstones and calcareous beds of the Benighat Slates. 
The major geological structures of the area are the Ghumaune Synclinorium and Jalbhanjyang Thrust. The core of the Ghumaune Synclinorium is occupied by the thick succession of slates of the BenighaSlates which is trending $275^{\circ}$ with the plunge of $7^{\circ}$. Other local folds in the area are the Bandipur Syncline and Hilekharka Anticline. Many small scale folds are also observed in the area. Several primary structures like ripple mark, mud crack, graded bedding and biogenic structures like stromatolites are also found in the study area and these features are used to assess the order of superposition and depositional sedimentary environments. Based on these primary structures the beds are found right side up in the study area expect the Bhut Khola-Bagar khola section where the north dipping beds are overturned.

The Jalbhanjyang Thrust has brought the Labdi Khola Member with Bandipur Slate over the Dhading Dolomite (Fig. 20). One outlier of Purebensi Quartzite within the Dandagaon Phyllite in Hilekharka area and two small outliers of Dhading Dolomite within the Nourpul Formation at the upper reaches of the Bandipur and Phalamdada area are mapped. The overall rocks of the study area belong to the chlorite zone of metamorphism.

\section{ACKNOWLEDGEMENTS}

This work is a part of Ph.D. research of K.R. Paudyal. $\mathrm{He}$ is thankful to Nepal Academy of Science and Technology (NAST) for Ph.D. grant. We express our sincere gratitude to the Central Department of Geology, Tribhuvan University for providing the laboratory facilities. We are thankful to Prof. Dr. Ram Bahadur Sah and Associate Prof. Dr. Naresh Tamrakar for their efforts to revise the manuscript. We extend our thanks to Deo Kumar Limbu, Roshan Koirala and Pramod Pandey for accompanying in the field.

\section{REfERENCES}

Arita, K., Ohta, Y., Akiba, C., Maruo, Y., 1973, Kathmandu region. In: Hashimoto, S., Ohta, Y., Akiba, C. (Eds.), Geology of the Nepal Himalayas, Saikon, Sapporo, pp. 99-145.

Auden, J.B., 1934. Traverses in the Himalaya. Records of the Geological Survey of India 69, 123-167. Bordet, P., Krumenacher, D., Mouterde, R; Remy, J.M.,
1964, Sur La Stratigraphic Des Series Affleurant Dans La Vall'ee De La Kali Gandaki (N'epal Central) Competes rendus Des S'eances De I'Academic Des Sciences Paris Serie D 259, 414, 416.

Colchen, M., Le Fort, P., Pêcher, A., 1980. Carte géologique Annapurna-Manaslu-Gahesh, Himalaya du Népal Echelle 1: 200,000, Centre National de la Recherche Scientifique, Paris.

Dhital, M.R., 1995. Mode of Occurrence of Nepheline Syenites in Gorkha-Ampipal area, Central Nepal Lesser Himalaya. Journal of Nepal Geological society Special Issue II, 159-170.

Dhital, M.R., Thapa, P.B., Ando, H., 2002, Geology of the inner Lesser Himalaya between Kusma and Syangja in western Nepal. Bulletin of the Department of Geology, Tribhuvan University 9, Sp. Issue, pp 1-69.

DMG (Department of Mines and Geology), 1987. Geological map of central Nepal in 1:2,50000 sclae. Publisehed by the DMG. Gansser, A., 1964, Geology of the Himalayas: Interscience Publishers, John Wiley and Sons, London, 289 p.

Hagen, T., 1969, Report on the Geological Survey of Nepal, Preliminary Reconnaissance. Zurich, Memoirs de la Soc. Helvetique des sci. Naturelles.

Hirayama, J., Nakajima, T., Shrestha, S.B., Adhikari, T.P., Tuladhar, R.M., Tamrakar, J.M., Chitrakar, G.R., 1988. Geology of southern part of the Lesser Himalaya, west Nepal. Bulletin of the Geological Survey of Japan 39, 205-249.

Jnawali, B.M., Tuladhar, G.B., 1996, Geological Map of Tanahu and Kaski Districts (scale, 1:50,000). Department of Mines and Geology, Kathmandu.

Paudel, L.P., Arita, K., 2000. Tectonic and polymetamorphic history of the Lesser Himalaya in central Nepal. Journal of Asian Earth Sciences 18, 561-584. http://dx.doi.org/10.1016/S1367-9120(99)00069-3

Paudyal, K. R. and Paudel, L. P., 2011. Geological setting and lithostratigraphy of the Lesser Himalaya in the Muglin Banspani area, central Nepal. Journal of Nepal Geological Society, v. 42, pp. 51-63.

Sakai, H., 1985, Geology of the Kali Gandaki Supergroup of the Lesser Himalaya in Nepal. Memoirs of Facility of Science, Kyushu University, Ser. D. (Geology, V. 25 93), pp. 337-397.

Stöcklin, J., 1980, Geology of the Nepal and its Regional Frame: Journal of the Geological Society of London, V. 137, pp. 1-34.

http://dx.doi.org/10.1144/gsjgs.137.1.0001

Stöcklin, J; Bhattarai, K.D., 1977. In: Himalaya Report Geology of Kathmandu Area and Central Mahabharat Range Nepal. Department of Mines and Geology Kathmandu, Nepal, 86 pp. 